\title{
Production of Thermostable Mutant Nitrilase by Recombinant Escherichia Coli
}

\author{
Kiran DB, Mahesh DP, Manoj JD, Gaurav SS and Uttam CB* \\ Department of Pharmaceutical Technology (Biotechnology), National Institute of Pharmaceutical Education and Research, India
}

Submission: September 18, 2017; Published: November 27, 2017

*Corresponding author: Uttam CB, Department of Pharmaceutical Technology (Biotechnology), Block-H, National Institute of Pharmaceutical Education and Research, Mohali-160062, Punjab, India, Email: ucbanerjee@niper.ac.in

\begin{abstract}
The effect of various process parameters and medium components on the growth and production of a thermo stable nitrilase by recombinant Escherichia coli BL21(DE3) was studied by response surface methodology. A fractional factorial design showed that the initial concentrations of glycerol, meat extract, Triton X-100 and post-induction harvest time significantly affected the nitrilase production. A full factorial CCD design showed that the optimal values of these factors to be $30 \mathrm{~g} / \mathrm{L}, 5 \mathrm{~g} / \mathrm{L}, 0.10 \% \mathrm{v} / \mathrm{v}$ and $6.0 \mathrm{~h}$, respectively for the maximum production of nitrilase. The constant process parameters were bactopeptone $10 \mathrm{~g} / \mathrm{L}$, IPTG $1.0 \mathrm{mM}, \mathrm{pH} 7.0$ and cultivation temperature of $25^{\circ} \mathrm{C}$. Compared to the Luria Bertani medium, the nitrilase activity in the optimized medium had increased by 3.5 folds while, that of the maximum cell mass concentration increased by 3 -folds. The optimized parameters were used as culture media during the large scale cultivation of the same micro-organism in a $14 \mathrm{~L}$ stirred tank bioreactor. At fermenter level, various physico-chemical parameters like agitation speed, aeration rate, temperature and $\mathrm{pH}$ of the medium were varied to determine suitable values of these variables for the maximum production of nitrilase.
\end{abstract}

Keywords: Recombinant Escherichia coli; Thermo stable nitrilase; Response surface method; Stirred tank bioreactor

\section{Introduction}

Recent developments in the field of molecular biology have potentiated their allied fields to accelerate the rate of drug synthesis process including biocatalyst is in an economically viable way [1]. Quite often the selected biocatalyst suffer from major lacunae of lacking the desired attributes such as reaction $\mathrm{pH}$, temperature, chemical stability etc. and hence at times cannot be used further for the transformation reactions in pharmaceutical industries [2]. Successful optimization of any biotransformation requires a highly productive fermentation system that has been carried out in a minimum cost possible. Also, there has been a pressing need for the synthesis of chiral compounds in biotechnological sectors that is continually demanding new and robust enzymes [3].

Nitrilases have gained tremendous importance for the environment-friendly bioconversion of mandelonitrile nitriles to mandelic acid with sufficiently fair yield and selectivity [4]. Production of heterologous enzymes in microorganisms is majorly affected by the composition of the culture medium and the conditions in which the organism is grown [5-9]. Response surface methodology (RSM) and factorial design are important tools to study the effect of both the primary factors and their mutual interactions $[10,11]$.
In our laboratory, site directed mutagenesis (alanine scanning mutagenesis) on the conserved amino acid residues of nitrilase gene (Gen Bank Accession No. EF467660) was carried, out of which T48A (Threonine at 48th position was replaced by Alanine) mutant turned out to have better thermo stability and oxidative stability profile without any compromise on the enantio selectivity and nitrile hydrolysis pattern [12]. The basic components of Luria Bertani medium have been widely reported as the minimum essential requirements for the cultivation of recombinant $E$. coli strains $[13,14]$. In the present investigation, we tried to improve the nitrilase production by supplementing Luria Bertani medium using central composite design [CCD] in shake flasks. Nitrilase production was assessed in a $14 \mathrm{~L}$ bioreactor under the optimized nutritional conditions and effect of various physico-chemical parameters like agitation speed, aeration rate, and cultivation temperature, initial $\mathrm{pH}$ of the medium and inducer concentration was studied in a bioreactor.

\section{Materials and Methods}

\section{Microorganism cultivation conditions}

Recombinant E. coli cell harboring the mutant nitrilase gene in pET 21b [+] [Novagen, Madison, USA] expression vector was 
used. The stock culture was maintained on Luria Bertani plates containing ampicillin (final concentration $100 \mu \mathrm{g} / \mathrm{mL}$ ) and the glycerol stocks were frequently stored at $-80^{\circ} \mathrm{C}$. For shake flasks studies, $10 \mu \mathrm{L}$ from glycerol stock was grown at $37^{\circ} \mathrm{C}$ for $12 \mathrm{~h}$ in an incubator $(200 \mathrm{rpm})$ in Luria Bertani medium. Inoculum $(1.0 \%$, $\mathrm{v} / \mathrm{v}$ ) was transferred to the production medium and grown for specified time at specified temperature at 200rpm to which IPTG (final concentration $1 \mathrm{mM}$ ) was added $2 \mathrm{~h}$ after inoculation.

\section{Optimization of physico-chemical parameters for the growth and production of nitrilase by Escherichia coli in shake flasks}

The environmental and nutritional parameters were optimized to maximize the cell mass growth and nitrilase production. The initial screening of the variables potentially affecting nitrilase production was carried out by fractional factorial design. The selected factors were then used in full factorial design to determine their optimum values.

\section{Fractional factorial design}

In screening experiments conducted according to a PlackettBurman design, the response $Y$ (i.e. the nitrilase activity in broth) was correlated with the values of the independent factors [Xi], as follows Patil et al. [11]:

$$
\mathrm{Y}=\beta_{0}+\sum \beta_{\mathrm{i}} \mathrm{X}_{\mathrm{i}}
$$

where, $\beta_{0}$ is the model intercept and $\beta_{\mathrm{i}}$ is the variable estimate.

Supplementary Table 1: The Placket-Burman experimental design matrix for the screening experiments.

\begin{tabular}{|c|c|c|c|c|c|c|c|c|c|c|c|c|c|c|c|c|c|c|c|c|c|c|c|}
\hline \multirow[t]{2}{*}{ 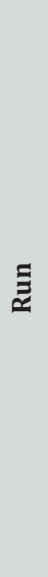 } & \multirow{2}{*}{ 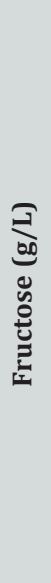 } & \multirow{2}{*}{ 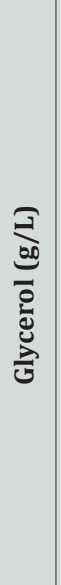 } & \multirow{2}{*}{ 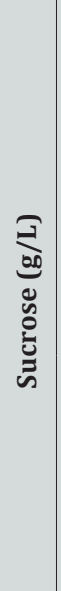 } & \multirow{2}{*}{ 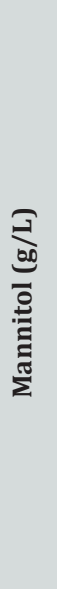 } & \multirow{2}{*}{ 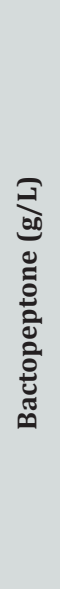 } & \multirow{2}{*}{ 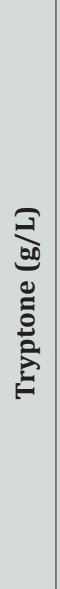 } & \multirow{2}{*}{ 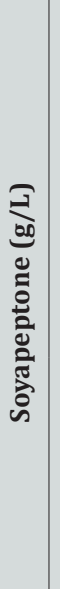 } & \multirow{2}{*}{ 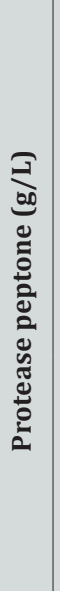 } & \multirow{2}{*}{ 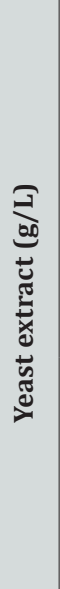 } & \multirow{2}{*}{ 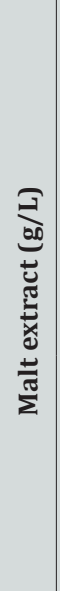 } & \multirow{2}{*}{ 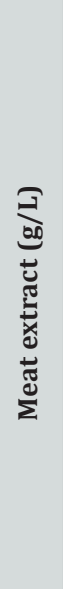 } & \multirow{2}{*}{ 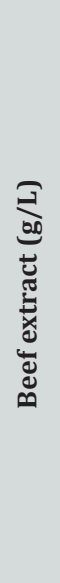 } & \multirow{2}{*}{ 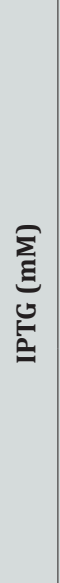 } & \multirow{2}{*}{ 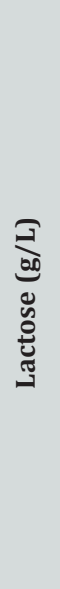 } & \multirow{2}{*}{ 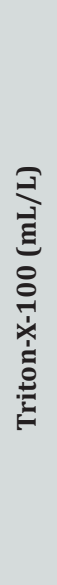 } & \multirow{2}{*}{ 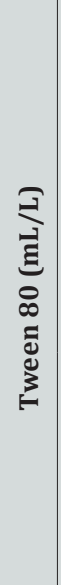 } & \multirow{2}{*}{ 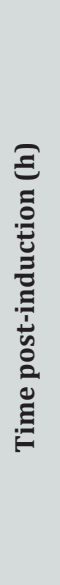 } & \multirow[t]{2}{*}{$\frac{\text { İ }}{\frac{\pi}{\pi}}$} & \multirow{2}{*}{ 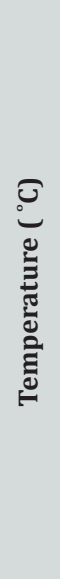 } & \multicolumn{2}{|c|}{ 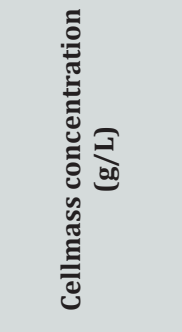 } & \multicolumn{2}{|c|}{ 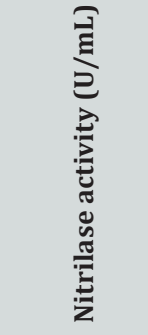 } \\
\hline & & & & & & & & & & & & & & & & & & & & 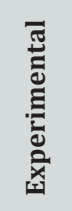 & 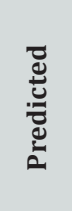 & 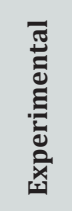 & 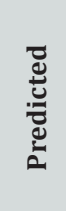 \\
\hline 1 & 10 & 10 & 10 & 10 & 20 & 20 & 5 & 20 & 10 & 2 & 2 & 10 & 1 & 20 & 4 & 1 & 18 & 6 & 37 & 0.73 & 0.75 & 0.38 & 0.38 \\
\hline 2 & 10 & 30 & 10 & 10 & 5 & 5 & 20 & 20 & 2 & 10 & 10 & 2 & 0.2 & 20 & 4 & 4 & 18 & 6 & 37 & 0.49 & 0.49 & 0.51 & 0.51 \\
\hline 3 & 30 & 30 & 30 & 10 & 20 & 5 & 20 & 5 & 2 & 2 & 2 & 10 & 1 & 0 & 4 & 4 & 6 & 6 & 37 & 0.45 & 0.47 & 0.3 & 0.3 \\
\hline 4 & 10 & 10 & 10 & 30 & 20 & 5 & 20 & 20 & 2 & 2 & 10 & 10 & 1 & 20 & 1 & 4 & 6 & 9 & 25 & 0.41 & 0.41 & 0.35 & 0.35 \\
\hline 5 & 30 & 30 & 10 & 30 & 20 & 5 & 5 & 20 & 10 & 10 & 10 & 2 & 1 & 0 & 4 & 1 & 6 & 6 & 25 & 0.39 & 0.37 & 0.39 & 0.39 \\
\hline 6 & 30 & 10 & 30 & 10 & 5 & 5 & 5 & 20 & 10 & 2 & 10 & 10 & 0.2 & 0 & 4 & 4 & 18 & 9 & 25 & 0.83 & 0.87 & 0.48 & 0.48 \\
\hline 7 & 30 & 30 & 10 & 10 & 20 & 20 & 20 & 20 & 2 & 10 & 2 & 10 & 0.2 & 0 & 1 & 1 & 18 & 9 & 25 & 0.49 & 0.49 & 0.54 & 0.54 \\
\hline 8 & 10 & 30 & 10 & 30 & 5 & 5 & 5 & 5 & 10 & 10 & 2 & 10 & 1 & 0 & 1 & 4 & 18 & 9 & 37 & 0.90 & 0.91 & 0.53 & 0.53 \\
\hline 9 & 10 & 10 & 30 & 30 & 20 & 20 & 5 & 20 & 2 & 10 & 2 & 2 & 0.2 & 0 & 4 & 4 & 6 & 9 & 37 & 1.08 & 1.06 & 0.36 & 0.36 \\
\hline 10 & 10 & 10 & 30 & 30 & 5 & 20 & 20 & 5 & 2 & 10 & 10 & 10 & 1 & 0 & 4 & 1 & 18 & 6 & 25 & 0.71 & 0.69 & 0.48 & 0.47 \\
\hline 11 & 30 & 10 & 10 & 10 & 5 & 20 & 20 & 5 & 10 & 10 & 2 & 2 & 1 & 20 & 4 & 4 & 6 & 9 & 25 & 0.42 & 0.44 & 0.29 & 0.29 \\
\hline 12 & 30 & 30 & 10 & 30 & 5 & 20 & 5 & 5 & 2 & 2 & 10 & 10 & 0.2 & 20 & 4 & 1 & 6 & 9 & 37 & 0.51 & 0.49 & 0.35 & 0.36 \\
\hline 13 & 30 & 10 & 10 & 30 & 20 & 20 & 20 & 5 & 10 & 2 & 10 & 2 & 0.2 & 0 & 1 & 4 & 18 & 6 & 37 & 0.47 & 0.47 & 0.51 & 0.51 \\
\hline 14 & 30 & 10 & 30 & 10 & 20 & 5 & 5 & 5 & 2 & 10 & 10 & 2 & 1 & 20 & 1 & 1 & 18 & 9 & 37 & 0.53 & 0.51 & 0.56 & 0.56 \\
\hline 15 & 10 & 30 & 30 & 10 & 5 & 20 & 20 & 20 & 10 & 2 & 10 & 2 & 1 & 0 & 1 & 1 & 6 & 9 & 37 & 0.56 & 0.56 & 0.37 & 0.36 \\
\hline 16 & 10 & 30 & 30 & 10 & 20 & 20 & 5 & 5 & 10 & 10 & 10 & 10 & 0.2 & 20 & 1 & 4 & 6 & 6 & 25 & 0.48 & 0.52 & 0.39 & 0.38 \\
\hline 17 & 10 & 10 & 10 & 10 & 5 & 5 & 5 & 5 & 2 & 2 & 2 & 2 & 0.2 & 0 & 1 & 1 & 6 & 6 & 25 & 1.04 & 1.02 & 0.37 & 0.37 \\
\hline 18 & 30 & 10 & 30 & 30 & 5 & 5 & 20 & 20 & 10 & 10 & 2 & 10 & 0.2 & 20 & 1 & 1 & 6 & 6 & 37 & 0.51 & 0.51 & 0.25 & 0.25 \\
\hline 19 & 30 & 30 & 30 & 30 & 5 & 20 & 5 & 20 & 2 & 2 & 2 & 2 & 1 & 20 & 1 & 4 & 18 & 6 & 25 & 0.50 & 0.48 & 0.54 & 0.54 \\
\hline 20 & 10 & 30 & 30 & 30 & 20 & 5 & 20 & 5 & 10 & 2 & 2 & 2 & 0.2 & 20 & 4 & 1 & 18 & 9 & 25 & 0.74 & 0.72 & 0.5 & 0.5 \\
\hline
\end{tabular}


The experimental design and the corresponding results are shown in supplementary Table 1 for the 20 different trials. To maximize the cell mass growth and nitrilase production, the variable factors and their effective ranges were selected based on preliminary experiments and the literature data [15-18].

\section{Full factorial design}

The levels of the four variables, identified via screening experiments to have the strongest influence on nitrilase titre, were optimized through a four factor-three level central composite experiment design. Constant factors in all the runs were: bactopeptone $10 \mathrm{~g} / \mathrm{L}$, IPTG $1 \mathrm{mM}$ and initial $\mathrm{pH}$ of the medium 7.0. The inoculums constituted $1 \%(\mathrm{v} / \mathrm{v})$ of the culture volume. The agitation rate and temperature used were 200rpm and $25^{\circ} \mathrm{C}$ respectively. To validate the predictability of the model, the separate experiment, in triplicate, was executed with the conditions recommended by point prediction module of Design Expert ${ }^{\mathrm{TM}}$ software. The maximum experimental values of both the responses were compared with the predicted values of the model. Multiple regression analysis was performed and first order polynomial equation for nitrilase production was generated. The response measured was correlated with the values of the factors using the following equation:

$\mathrm{Y}_{1}=1.88+0.39 \mathrm{~A}-0.2 \mathrm{~B}-0.057 \mathrm{C}-0.25 \mathrm{D}-0.15 \mathrm{AB}-0.004 \mathrm{AC}-$ $0.21 A D-0.079 B C+0.079 B D+0.16 C D-0.16 A^{\wedge} 2+0.41 B^{\wedge} 2-0.11 C^{\wedge} 2-$ $0.088 \mathrm{D}^{\wedge} 2$

In the above equation, $\mathrm{Y}_{1}$ is the response (nitrilase activity, $\mathrm{U} / \mathrm{mL}) ; \mathrm{A}(\mathrm{g} / \mathrm{L})$ is the concentration of glycerol; $\mathrm{B}(\mathrm{g} / \mathrm{L})$ is the concentration of meat extract; and $\mathrm{C}(\mathrm{mL} / \mathrm{L})$ is the concentration of Triton $\mathrm{X}-100$ and $\mathrm{D}(\mathrm{h})$ is post-induction time.

\section{Optimization of physico-chemical parameters for the growth and production of nitrilase by Escherichia coli in a stirred tank bioreactor}

Bioreactor studies were carried out aseptically in a $14 \mathrm{~L}$ stirred-tank bioreactor [Bio Flo 310, New Brunswick Scientific, Co., Inc., NJ, USA] with a working volume of $8 \mathrm{~L}$. The bioreactor containing medium was autoclaved at $121^{\circ} \mathrm{C}$ for $15 \mathrm{~min}$ and allowed to cool down to room temperature. $\mathrm{pH}$ was monitored using a glass electrode immersed in the fermentation broth while dissolved oxygen was measured using a polar graphic electrode (In gold, Leicester, U.K.). The inoculums volume was kept $10 \%(\mathrm{v} / \mathrm{v})$ level for all the bioreactor studies. The temperature was controlled at $25{ }^{\circ} \mathrm{C}$ unless otherwise specified. IPTG is relatively expensive and has been shown detrimental for the growth of $E$. coli cells [19-21].

Lactose was therefore used as a good replacement as it serves dual advantage of acting as an inducer for the over expression of proteins in T7 promoter driven pET system and also as growth enhancer to the cells Lodish et al. [22]. The initial concentrations of bactopeptone and lactose were always $10 \mathrm{~g} / \mathrm{L}$ each unless otherwise specified. Triton X-100 surfactant was completely omitted from the fermenter run as even the slightest presence of surfactant results in prolific foaming in the fermentation broth Patil et al. [11]. Agitation was provided by a Rushton turbine type (flat-bladed impeller) agitator at the specified values in different experiments. Sterile air was sparged through the reactor at specified values for different runs. Dissolved oxygen (DO) calibration was performed with air (100\%) and nitrogen $(0 \%)$. Foaming was controlled with the intermittent drop-wise addition of sterile polypropylene glycol (Sigma-Aldrich; catalog no. 202339) through peristaltic pump. Fermentation parameters such as temperature, dissolved oxygen, $\mathrm{pH}$, agitation, aeration rate were adjusted by the means of digitally controlled system. Fermentations were generally run for $20-22 \mathrm{~h}$ or unless a stationary phase was attained. Samples were taken from the reactor at every $2 \mathrm{~h}$ to measure cell mass concentration, nitrilase activity and residual lactose concentration. For optimization studies at higher scale, batch experiments were executed under varying range of temperature, agitation, aeration rate, $\mathrm{pH}$ and inducer concentration to maximize the growth and production of nitrilase by E.coli BL21(DE3).

\section{Analytical methods}

Estimation of nitrilase activity: Nitrilase activity was determined using a modified Berthelot assay method [Reference]. In the modified Berthelot assay method, the released ammonia (as a byproduct) was estimated. One unit of nitrilase activity was defined as the amount of enzyme that liberates $1 \mu \mathrm{mol}$ of ammonia per min at $37^{\circ} \mathrm{C}$. The amount of ammonia produced from the hydrolysis of phenoxy acetonitrile was estimated as previously reported Weatherburn [23]. A calibration curve for ammonium chloride was produced by diluting a $3 \mathrm{mM}$ stock solution of ammonium chloride to various concentrations $(0.25-3.00 \mathrm{mM})$. In a glass test tube, $500 \mu \mathrm{L}$ of the diluted ammonium chloride solution was mixed with $1.5 \mathrm{~mL}$ of Berthelot solution A by slight vortexing. After 5 minutes, $1.5 \mathrm{~mL}$ of Berthelot solution B was added and mixed by vortexing. The mixture was incubated at $95^{\circ} \mathrm{C}$ for $5 \mathrm{~min}$, cooled and the spectro photometric absorbance was measured at $640 \mathrm{~nm}$ against a blank of distilled water treated the same way as the ammonium chloride standard solution. The measured absorbance was plotted against the known concentration of ammonium chloride to obtain a calibration curve. Volumetric production of nitrilase has been reported in terms of $\mathrm{U} / \mathrm{mL}$ in shake flaks as well as in fermenter studies.

Estimation of cell mass concentration: The bacterial cell mass in the fermentation broth was quantified by measuring the optical density at $600 \mathrm{~nm}$ in a UV double beam spectrophotometer (Hitachi U-3010, Japan). The calibration curve was generated by measuring the optical density of a serially diluted broth sample having a precisely known cell mass dry weight concentration.

Estimation of residual glycerol: Residual glycerol concentration in the culture supernatant was determined using the stannous chloride-sodium periodate method [24]. 
Estimation of residual lactose: Residual lactose concentration in the supernatant of fermentation broth was determined using the 3, 5-dinitro salicylic acid (DNSA) method [25].

\section{Results and Discussion}

\section{Growth and production of nitrilase by Escherichia coli using statistical methods in shake flasks}

Evaluation of the factors affecting nitrilase production using fractional factorial design: ANOVA of screening experiments is shown in Supplementary Table 2. The correlation coefficient [R] of the model was 0.995 , indicating a good agreement between the experimental values and the values predicted by the model. As the concentration of glycerol, concentration of meat extract, concentration of Triton X-100 and the post induction harvest time were the most influential factors, with confidence levels of 99.86, 99.78, 99.83 and 99.99\%, respectively, they were selected for optimization studies by the central composite design. Unlike glucose, glycerol has an added advantage of not causing any acetate excretion when used as the carbon source in the fermentation medium [14]. Due to non-interference in lac operon pathway, glycerol also has been reported to be the best carbon source for the high cell density fermentation using inducible systems such as recombinant E. coli [26].

Supplementary Table 2: Statistical analysis of Plackett-Burman design for nitrilase production.

\begin{tabular}{|c|c|c|c|c|c|c|}
\hline Variable & SS & DF & MS & F-ratio & P-value & B-coefficient \\
\hline B-Glycerol & 0.008 & 1 & 0.008 & 717.09 & $0.0014^{*}$ & 0.02 \\
\hline D-Mannitol & 0.008 & 1 & 0 & 41.6 & 0.0232 & 0.005 \\
\hline E-Bacto Peptone & 0.008 & 1 & 0.001 & 66.59 & 0.0147 & 0.006 \\
\hline F-Tryptone & 0.008 & 1 & 0 & 6.72 & 0.1221 & -0.002 \\
\hline G-Soyapeptone & 0.008 & 1 & 0.004 & 329.94 & 0.003 & -0.014 \\
\hline H-Protease peptone & 0.008 & 1 & 0.001 & 45.36 & 0.0213 & -0.005 \\
\hline J-Yeast extract & 0.008 & 1 & 0.004 & 351.97 & 0.0028 & -0.014 \\
\hline K-Malt extract & 0.008 & 1 & 0.001 & 86.5 & 0.0114 & 0.007 \\
\hline L-Meat extract & 0.008 & 1 & 0.005 & 460.54 & $0.0022^{*}$ & 0.016 \\
\hline M-Beef extract & 0.008 & 1 & 0.006 & 527.83 & 0.0019 & -0.017 \\
\hline N-IPTG & 0.008 & 1 & 0 & 24.36 & 0.0387 & -0.004 \\
\hline O-Lactose & 0.008 & 1 & 0.002 & 207.24 & 0.0048 & -0.011 \\
\hline P-Triton-X-100 & 0.008 & 1 & 0.006 & 571.69 & $0.0017^{*}$ & -0.018 \\
\hline Q-Tween 20 & 0.008 & 1 & 0 & 25.42 & 0.0372 & 0.004 \\
\hline R-Time (Post-induction) & 0.008 & 1 & 0.13 & 11559.46 & $<0.0001^{*}$ & 0.08 \\
\hline S-Initial pH & 0.008 & 1 & 0.003 & 237.24 & 0.0042 & 0.012 \\
\hline T-Temperature & 0.008 & 1 & 0.002 & 190.41 & 0.0052 & -0.01 \\
\hline
\end{tabular}

*Factors selected for CCD SS: Sum of Squares; DF: Degrees of Freedom; MS: Mean Sum of squares.
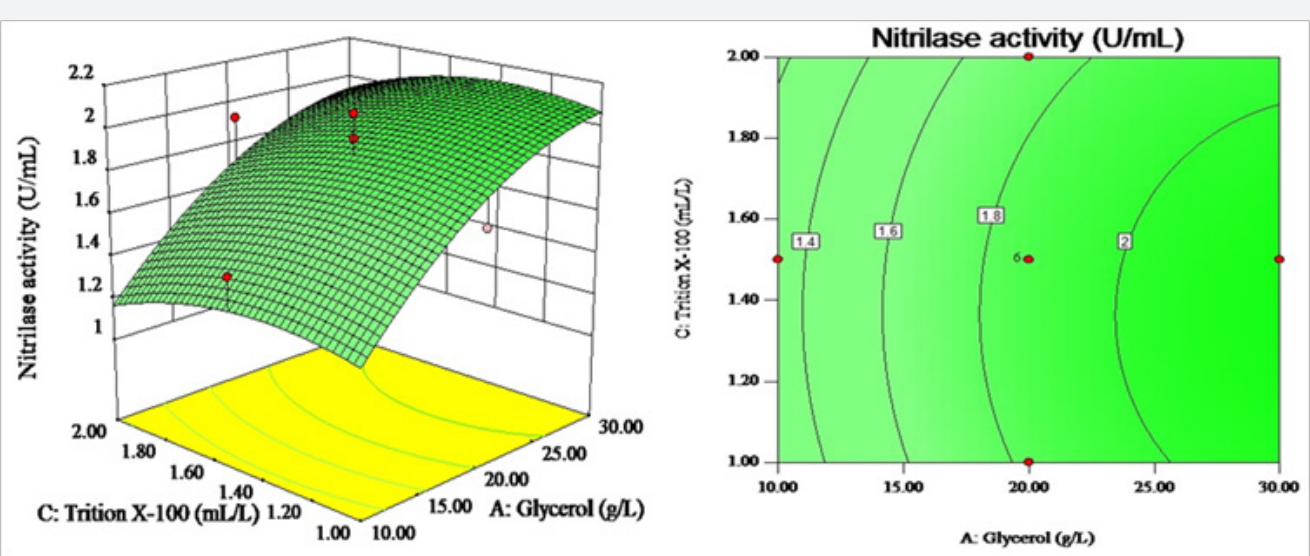

Figure 1: Response surface and contour plot showing the interactive effect of glycerol concentration on the nitrilase activity.

Central composite design: The predicted and measured responses of the experiments are also shown in Table 1 and they were found to be in good agreement $[R=]$. The maximum nitrilase activity of $3.37 \mathrm{U} / \mathrm{mL}$ was measured in run 28 and the corresponding predicted activity was $3.36 \mathrm{U} / \mathrm{mL}$, which was within $5 \%$ of the predicted value Table 1 . The ANOVA of the model 


\section{Advances in Biotechnology \& Microbiology}

(Equation 2) is shown in Table 2. The determination coefficient [R2] of the model (Equation 1) was 0.94; therefore, the model could explain $94 \%$ of the variation in the predicted responses of the nitrilase activity. The 'adequate precision value', an index of the signal-to-noise ratio, of Equation 1 was 18.943 suggesting that the model could be used to navigate the design space. An adequate precision value of greater than 4 is a prerequisite for a model to be considered a good fit to the data [11]. In view of Table 1, the concentration of glycerol had the strongest influence on the nitrilase activity. The response surface and contour plots generated for the interactive effect of glycerol and Triton X-100 are shown in Figure 1.

Table 1: Experimental setup for central composite design matrix.

\begin{tabular}{|c|c|c|c|c|c|c|}
\hline \multirow[t]{2}{*}{ Run } & \multirow{2}{*}{$\begin{array}{c}\text { Glycerol } \\
(\mathrm{g} / \mathrm{L})\end{array}$} & \multirow{2}{*}{$\begin{array}{c}\text { Meat Extract } \\
(\mathrm{g} / \mathrm{L})\end{array}$} & \multirow{2}{*}{$\begin{array}{l}\text { Triton X-100 } \\
\text { (mL/L) }\end{array}$} & \multirow{2}{*}{$\begin{array}{c}\text { Time Post-Induction } \\
\text { (h) }\end{array}$} & \multicolumn{2}{|c|}{ Nitrilase Activity (U/mL) } \\
\hline & & & & & Actual Value & Predicted Value \\
\hline 1 & 20 & 10 & 1.5 & 12 & 1.73 & 1.88 \\
\hline 2 & 10 & 15 & 2 & 6 & 1.04 & 1.17 \\
\hline 3 & 30 & 15 & 1 & 18 & 1.68 & 1.58 \\
\hline 4 & 10 & 10 & 1.5 & 12 & 1.48 & 1.33 \\
\hline 5 & 30 & 15 & 2 & 6 & 2.13 & 2.05 \\
\hline 6 & 10 & 5 & 1 & 6 & 1.94 & 1.84 \\
\hline 7 & 30 & 5 & 2 & 18 & 2.23 & 2.33 \\
\hline 8 & 10 & 5 & 2 & 6 & 1.5 & 1.58 \\
\hline 9 & 20 & 10 & 1.5 & 6 & 1.94 & 2.04 \\
\hline 10 & 20 & 10 & 1.5 & 12 & 1.77 & 1.88 \\
\hline 11 & 20 & 10 & 1 & 12 & 1.69 & 1.83 \\
\hline 12 & 20 & 10 & 1.5 & 12 & 1.75 & 1.88 \\
\hline 13 & 10 & 5 & 1 & 18 & 1.22 & 1.29 \\
\hline 14 & 20 & 10 & 1.5 & 12 & 1.77 & 1.88 \\
\hline 15 & 30 & 15 & 1 & 6 & 2.56 & 2.64 \\
\hline 16 & 20 & 10 & 1.5 & 18 & 1.71 & 1.54 \\
\hline 17 & 20 & 10 & 1.5 & 12 & 1.95 & 1.88 \\
\hline 18 & 10 & 5 & 2 & 18 & 1.7 & 1.65 \\
\hline 19 & 20 & 5 & 1.5 & 12 & 2.4 & 2.49 \\
\hline 20 & 30 & 5 & 2 & 6 & 3.17 & 3.07 \\
\hline 21 & 30 & 15 & 2 & 18 & 1.49 & 1.61 \\
\hline 22 & 10 & 15 & 1 & 18 & 1.38 & 1.51 \\
\hline 23 & 30 & 10 & 1.5 & 12 & 2.02 & 2.11 \\
\hline 24 & 20 & 10 & 2 & 12 & 1.92 & 1.71 \\
\hline 25 & 20 & 15 & 1.5 & 12 & 2.25 & 2.09 \\
\hline 26 & 20 & 10 & 1.5 & 12 & 2.06 & 1.88 \\
\hline 27 & 10 & 15 & 2 & 18 & 1.56 & 1.56 \\
\hline 28 & 30 & 5 & 1 & 6 & 3.37 & 3.36 \\
\hline 29 & 30 & 5 & 1 & 18 & 2.07 & 1.98 \\
\hline 30 & 10 & 15 & 1 & 6 & 1.86 & 1.75 \\
\hline
\end{tabular}

Table 2: Analysis of variance for response surface quadratic model for nitrilase production.

\begin{tabular}{|c|c|c|c|c|c|}
\hline Source & SS & DF & MS & F- value & P-value Prob>F \\
\hline Model & 6.75 & 14 & 0.48 & 18.12 & $<0.0001$ \\
\hline A-Glycerol (g/L) & 2.76 & 1 & 2.76 & 27.52 & $<0.0001$ \\
\hline B-Meat extract (g/L) & 0.73 & 1 & 0.73 & 2.21 & 0.0001 \\
\hline $\begin{array}{c}\text { C-Triton X-100 } \\
\text { (mL/L) }\end{array}$ & 0.059 & 1 & 0.059 & & 0.1574 \\
\hline
\end{tabular}




\begin{tabular}{|c|c|c|c|c|c|}
\hline $\begin{array}{l}\text { D-Time (post- } \\
\text { induction) (h) }\end{array}$ & 1.1 & 1 & 1.1 & 41.43 & $<0.0001$ \\
\hline $\mathrm{AB}$ & 0.38 & 1 & 0.38 & 14.33 & 0.0018 \\
\hline $\mathrm{AC}$ & 0 & 1 & 0 & 0.01 & 0.9232 \\
\hline $\mathrm{AD}$ & 0.67 & 1 & 0.67 & 25.36 & 0.0001 \\
\hline $\mathrm{BC}$ & 0.099 & 1 & 0.099 & 3.7 & 0.0735 \\
\hline $\mathrm{BD}$ & 0.1 & 1 & 0.1 & 3.76 & 0.0714 \\
\hline $\mathrm{CD}$ & 0.4 & 1 & 0.4 & 14.91 & 0.0015 \\
\hline A2 & 0.065 & 1 & 0.065 & 2.44 & 0.1391 \\
\hline B2 & 0.44 & 1 & 0.44 & 16.5 & 0.001 \\
\hline $\mathrm{C} 2$ & 0.029 & 1 & 0.029 & 1.09 & 0.3129 \\
\hline D2 & 0.02 & 1 & 0.02 & 0.76 & 0.3972 \\
\hline Residual & 0.4 & 15 & 0.027 & & \\
\hline Lack of Fit & 0.31 & 10 & 0.031 & 1.69 & 0.2929 \\
\hline Pure Error & 0.091 & 5 & 0.018 & & \\
\hline Cor Total & 7.15 & 29 & & & \\
\hline
\end{tabular}

The nitrilase activity increased with the increasing concentration of glycerol up to $30 \mathrm{~g} / \mathrm{L}$, right up-to its maximum concentration tested Figure 1. Triton X-100 had a minimal effect on nitrilase activity at the levels tested, but somewhat lower concentration of Triton X-100 appeared to favour nitrilase production. For the maximum production of heterologous protein from various $E$. coli expression strain, different incubation times after induction have been reported $[13,19,27,28]$. In the present work, screening experiments revealed a significant effect of time both in Plackett Burman as well as in central composite design. The statistical model (Equation 1) was validated at the combination of the optimum values of the four independent variables which were: an initial glycerol concentration of $30 \mathrm{~g} / \mathrm{L}$, initial meat extract concentration of $5 \mathrm{~g} / \mathrm{L}$, initial Triton X-100 concentration of $0.1 \%(\mathrm{v} / \mathrm{v})$ and a post induction harvest time of $6 \mathrm{~h}$. Compared with the lowest value obtained in PB design, the nitrilase activity in the optimized medium improved 15 -fold from 0.25 to $3.6 \mathrm{U} / \mathrm{mL}$.

\section{Growth and production of thermostable nitrilase by Escherichia coli in stirred tank bioreactor}

Effect of agitation: For the maximum growth of and heterologous protein production by a microorganism, the surrounding dissolved oxygen concentration is very crucial in aerobic fermentation. It is generally established by the optimum combination of aeration and agitation Parekh et al. [29]. Amongst the three different agitation runs, maximum activity was observed with the agitation rate of $300 \mathrm{rpm}$, while cell mass was maximum at $400 \mathrm{rpm}$. In agitation rates of 200 and 400rpm, which represent lower and higher stress condition respectively, gave poor results in comparison to $300 \mathrm{rpm}$ run. At $200 \mathrm{rpm}$, maximum nitrilase activity was $0.680 \mathrm{U} / \mathrm{mL}$, specific growth rate was $0.379 \mathrm{~h}^{-1}$ but maximum cell mass obtained was only $1.79 \mathrm{~g} / \mathrm{L}$. While at $400 \mathrm{rpm}$, maximum cell mass obtained was $4.18 \mathrm{~g} / \mathrm{L}$ but the specific growth rate and maximum nitrilase activity were only $0.025 \mathrm{~h}^{-1}$ and $0.107 \mathrm{U} / \mathrm{mL}$, respectively Figure 2 . The reason for lesser cell mass obtained at 200rpm can be attributed to the depleted dissolved oxygen levels experienced by the organism due to insufficient mixing. On the other hand, at an agitation rate of 300rpm, maximum cell mass obtained was $4.3 \mathrm{~g} / \mathrm{L}$, maximum nitrilase activity was $0.719 \mathrm{U} / \mathrm{mL}$ and the specific growth rate was only $0.164 \mathrm{~h}-1$. In all the three runs, in the presence of two carbon sources i.e.: lactose and glycerol, E. coli did not seem to utilize glycerol (as observed from the consumption graph in Supplementary Figure 1). Hence, glycerol was skipped in the subsequent fermenter runs and an agitation rate of 300rpm was used.

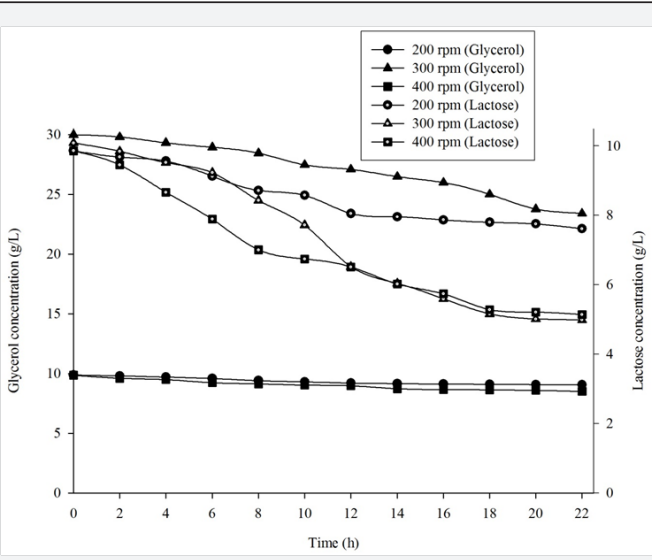

Supplementary Figure 1: Glycerol and lactose consumption profile at different agitation rates of 200,300 and 400 rpm and aeration rate of $0.75 \mathrm{vvm}$ in a stirred tank bioreactor. 


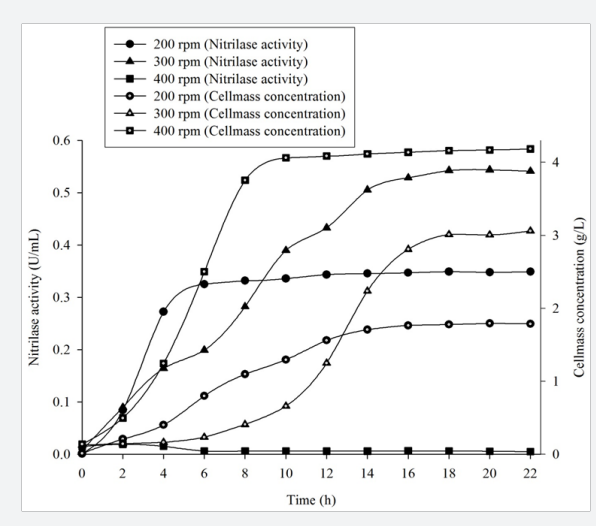

Figure 2: Effect of agitation rate on the growth and production of nitrilase in a stirred tank bioreactor. [In all runs, aeration rate was $0.75 \mathrm{vvm}$, temperature was $25^{\circ} \mathrm{C}$, and $\mathrm{pH}$ was uncontrolled].

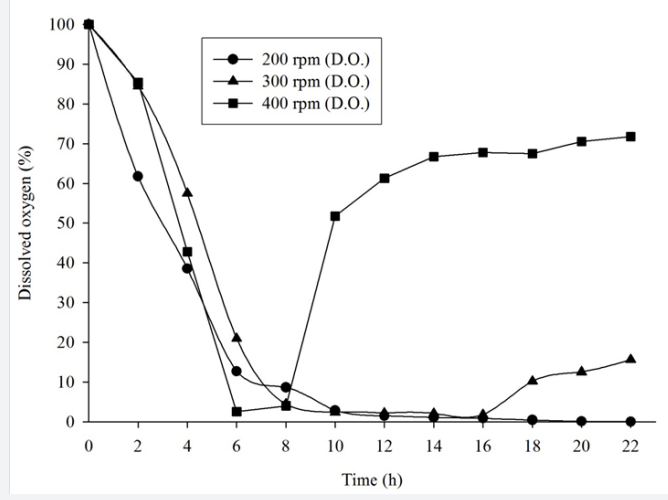

Supplementary Figure 2: Dissolved oxygen profile at different agitation rates of 200,300 and $400 \mathrm{rpm}$ and aeration rate of $0.75 \mathrm{vvm}$ in a stirred tank bioreactor.

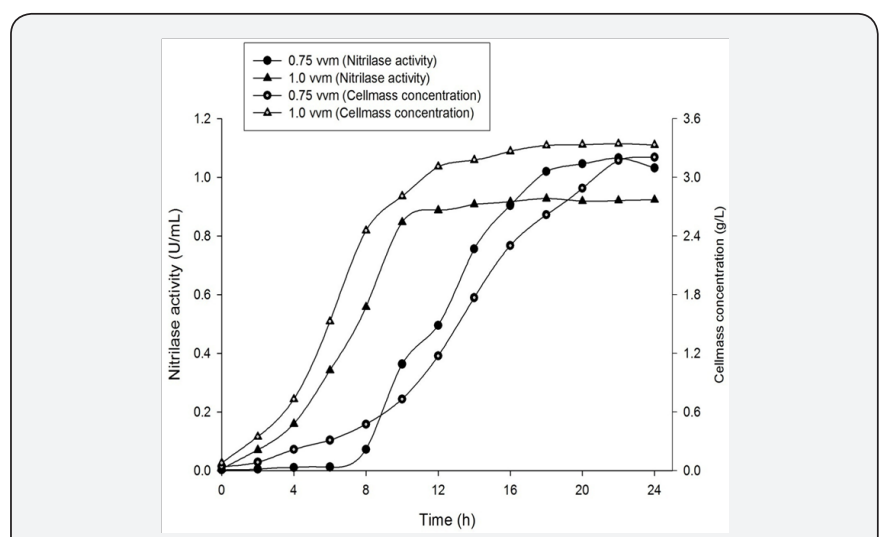

Figure 3: Effect of aeration rate on the growth and production of nitrilase in a stirred tank bioreactor. [In all runs, agitation rate was $300 \mathrm{rpm}$, temperature was $25^{\circ} \mathrm{C}$, and $\mathrm{pH}$ was uncontrolled].

Effect of aeration: Considering the problem of oxygen limitation in the fermenter broth, aeration rate was needed to be optimized to prevent the oxygen depleted state Supplementary Figure 2. At the aeration rates of $0.75 \mathrm{vvm}$ and $1.0 \mathrm{vvm}$, the maximum cell mass was 3.20 and $3.34 \mathrm{~g} / \mathrm{L}$, respectively, the maximum nitrilase activity was 1.07 and $0.93 \mathrm{U} / \mathrm{mL}$ and the specific growth rate was 0.155 and $0.10 \mathrm{~h}-1$, respectively (Figure 3). A slight increment in the aeration rate by $0.25 \mathrm{vvm}$ did not significantly affect the nitrilase activity and cell mass growth. None the less, the oxygen depletion state was prevented with increasing aeration rate (Supplementary Figure 3). Higher aeration rates have been reported to increase the growth of E.coli by improving the rate of oxygen transfer, but have a demerit of decreasing the enzyme activity by oxidizing the labile nitrilase residues there by impeding its activity Banerjee et al. [30]. Hence, aeration rate of $1.0 \mathrm{vvm}$ was used in next runs.
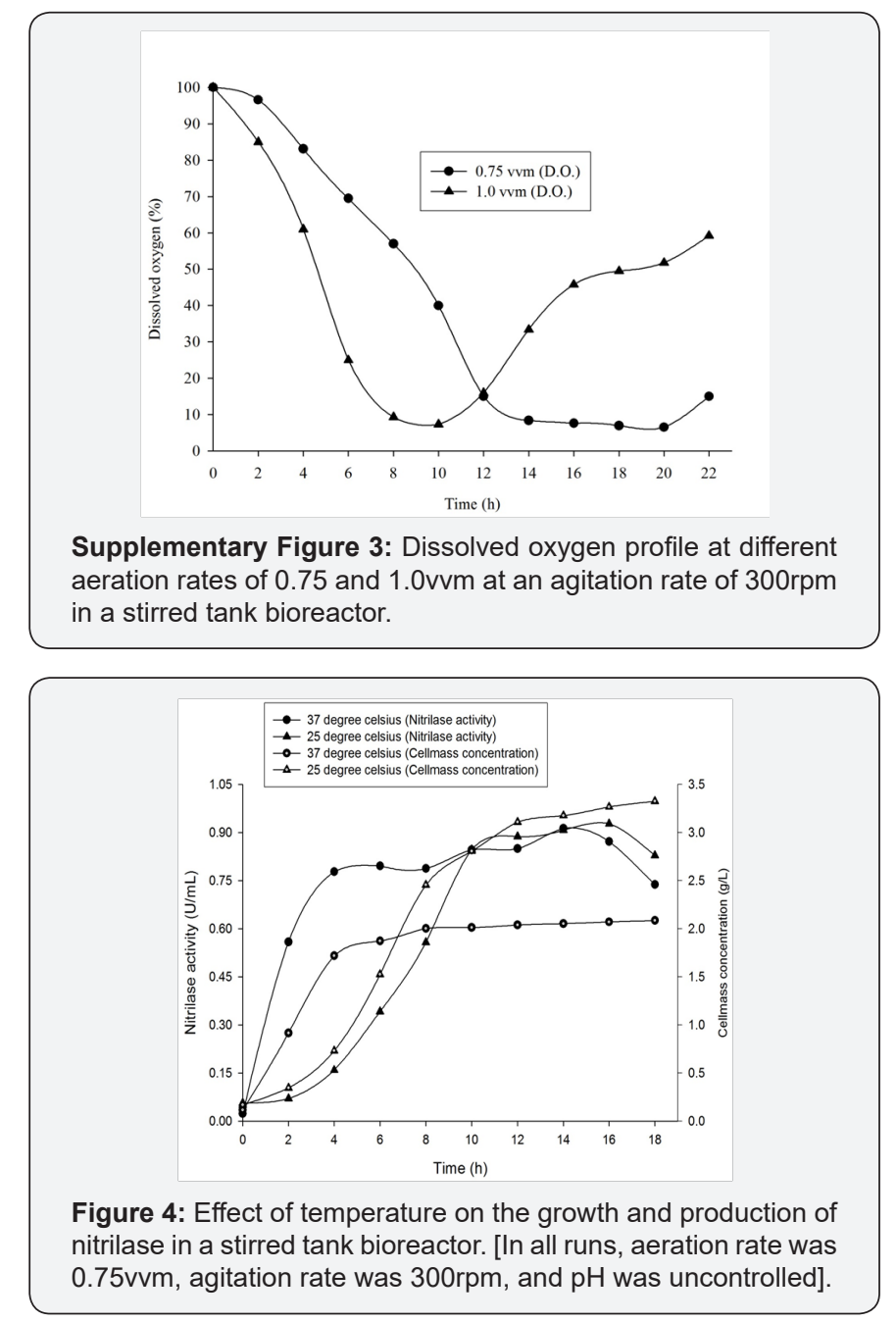

Effect of temperature: Temperature plays a crucial role in the course of fermentation as it drastically affects the growth rate of microorganism Doran [31]. In the present case, we used two temperatures, viz-25 and $37{ }^{\circ} \mathrm{C}$ to check nitrilase productivity profile. Increasing the cultivation temperature from $25^{\circ} \mathrm{C}$ to $37^{\circ} \mathrm{C}$ did improved the specific growth rate but with comparatively less cell mass formation (Figure 4). At $37^{\circ} \mathrm{C}$, specific growth rate and maximum cell mass obtained were $0.292 \mathrm{~h}^{-1}$ and $2.09 \mathrm{~g} / \mathrm{L}$, less than that obtained at $25^{\circ} \mathrm{C}$ where the values were $0.1009 \mathrm{~h}$ 1 and 3.32g/L. Maximum expression of Staphylococcal protein A in E. coli had decreased at $37^{\circ} \mathrm{C}$ compared to lower temperature Rigi et al. [32]. Weickert et al. [16] reported more soluble 
protein expression at temperature lesser than $30{ }^{\circ} \mathrm{C}$ Weickert et al. [16]. Our results are pretty much in agreement with these studies. We did not advance for still lower temperature since temperature equal to or less than $20{ }^{\circ} \mathrm{C}$ tend to decrease E. coli cell mass formation Volonte et al. [13]. Hence, all the subsequent fermented runs were carried out at $25^{\circ} \mathrm{C}$.

Effect of controlled pH: In most of the fermenter runs, the final $\mathrm{pH}$ of the fermenter medium near the stationary phase was found to be less than 6.0. Recombinant E. coli when grown under optimum oxygen supply in presence of the carbon source has been reported to excrete organic acids, mainly acetates, in good amounts and also responsible for the drop in $\mathrm{pH}$ of the fermentation broth $[33,34]$. It must be very difficult for the microorganism to survive and multiply that too when the dissolved oxygen concentration of the environment is less than $5 \%$. In 400rpm run, E. coli had entered the stationary phase quite early (12h)as soon as the $\mathrm{pH}$ was near 5(Data not shown). $\mathrm{pH}$ has always been a special consideration for the optimization studies during the high cell density growth of E. coli Shiloach \& Fass [14].

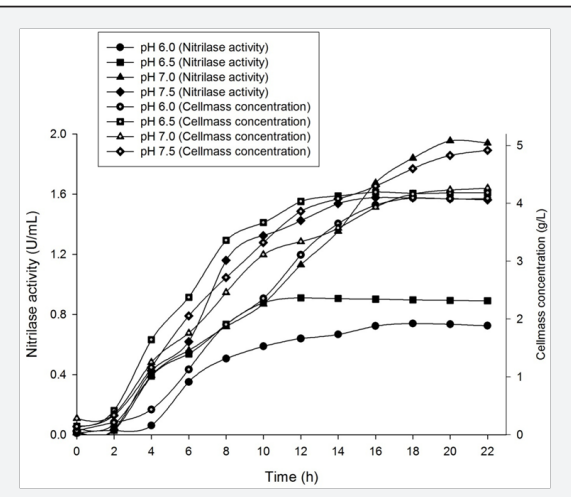

Figure 5: Effect of different controlled $\mathrm{pH}$ on the growth and production of nitrilase in a stirred tank bioreactor. [In all runs, aeration rate was $0.75 \mathrm{vvm}$, agitation rate was $300 \mathrm{rpm}$, and temperature was $25^{\circ} \mathrm{C}$ ].

Out of the four $\mathrm{pH}$ conditions (viz-6.0, 6.5, 7.0 and 7.5) that we used in the present study, $\mathrm{pH} 7.0$ gave the best result in terms of nitrilase activity as well as the specific growth rate. With controlled $\mathrm{pH}$, there was an improvement in both the production of cell mass as well as nitrilase activity. At pH 7.0, the maximum cell mass of $4.3 \mathrm{~g} / \mathrm{L}$ was achieved at $22 \mathrm{~h}$ of fermentation with maximum nitrilase activity of $1.96 \mathrm{U} / \mathrm{mL}$ (Figure 5). Since there was no fall in $\mathrm{pH}$, the cells entered stationary phase after prolonged 20h duration of fermentation. Although, most of the dissolved oxygen concentration had fallen nearly zero after $8 \mathrm{~h}$ of inoculation, even in the presence of minimal dissolved oxygen state, the cells kept dividing (Supplementary Figure 4). When the $\mathrm{pH}$ was tuned from neutral $\mathrm{pH}$ of 7.0 to acidic $\mathrm{pH}$ of 6.0, 6.5 and an alkaline $\mathrm{pH}$ of 7.5, there was marginal decrease in the maximum cell mass growth, whereas the maximum activity decreased was in the order: Acidic (pH-6) < Slightly acidic ( $\mathrm{pH}-6.5)<$ Alkaline $(\mathrm{pH}-7.5)<$ Neutral $(\mathrm{pH}-7)$. Specific growth rate for the different pH conditions was in the order: $0.057 \mathrm{~h}^{-1}(\mathrm{pH}-6.5)<0.076 \mathrm{~h}-1(\mathrm{pH}-$
6) $<0.087 \mathrm{~h}^{-1}(\mathrm{pH}-7.5)<0.108 \mathrm{~h}-1(\mathrm{pH}-7)$. Even slight alkaline or acidic $\mathrm{pH}$ was significantly negating the maximum nitrilase activity with only neutral $\mathrm{pH}$ giving the best result.

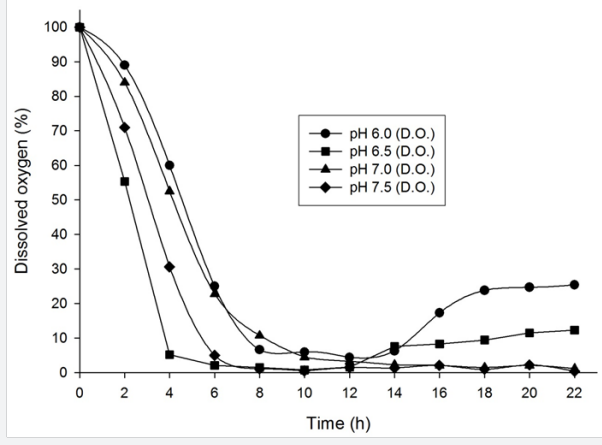

Supplementary Figure 4: Dissolved oxygen profile at different $\mathrm{pH}$ of $6.0,6.5,7.0$ and 7.5 at an agitation rate of 300rpm and aeration rate of $1.0 \mathrm{vvm}$ in a stirred tank bioreactor.

\section{Conclusion}

The best conditions for nitrilase production $(3.37 \mathrm{U} / \mathrm{mL})$ in a batch shake flask fermentation were as follows: an initial $\mathrm{pH} 7.0$; temperature $25^{\circ} \mathrm{C}$; an agitation rate 200rpm; IPTG $1 \mathrm{mM}$; with the following medium components- glycerol $30 \mathrm{~g} / \mathrm{L}$, tryptone $10 \mathrm{~g} / \mathrm{L}$, bactopeptone $10 \mathrm{~g} / \mathrm{L}$, yeast extract $5 \mathrm{~g} / \mathrm{L}$, meat extract $5 \mathrm{~g} / \mathrm{L}$ and Triton X-100 $0.10 \%(\mathrm{v} / \mathrm{v})$. Optimization of the fermentation conditions enhanced the nitrilase titre by 3.5 -fold relative to the Luria Bertani medium, used as the basal medium. The optimal conditions for the production of nitrilase in a stirred tank bioreactor were as follows: an agitation rate $300 \mathrm{rpm}$; an aeration rate $1.0 \mathrm{vvm}$; temperature $25^{\circ} \mathrm{C}$; a controlled pH 7.0 with the following concentrations of the components in the medium - lactose $10 \mathrm{~g} / \mathrm{L}$, tryptone $10 \mathrm{~g} / \mathrm{L}$, bactopeptone $10 \mathrm{~g} / \mathrm{L}$, yeast extract $5 \mathrm{~g} / \mathrm{L}$, meat extract $5 \mathrm{~g} / \mathrm{L}$.The peak nitrilase activity was found to be $1.96 \mathrm{U} / \mathrm{mL}$ in this condition. Significant variability in the response (growth profile and nitrilase activity) at shake flask and laboratory scale fermenter may be attributed to the differential shear stress experienced by E. coli in both the cases.

\section{Acknowledgment}

KDB and MDP gratefully acknowledge Department of Biotechnology (DBT), New Delhi, India, for the award of Senior Research Fellowships. Authors are thankful to Mr. Shubham Chinchulkar, Mr. Shrikant Raskar and Mr. Mukesh Kumar for their technical assistance with the bioreactor runs. $\mathrm{R}^{2}=0.9442$; adjusted $\mathrm{R}^{2}=0.8921$; predicted $\mathrm{R}^{2}=0.7348$; adequate precision=18.943; coefficient of variation $(\%)=8.54$. The determination coefficient $\left[\mathrm{R}^{2}\right]$ of the model (Equation 1) was 0.94; therefore, the model could explain $94 \%$ of the variation in the predicted responses of the nitrilase activity. The 'adequate precision value', an index of the signal-to-noise ratio, of Equation 1 was 18.943 suggesting that the model could be used to navigate the design space. An adequate precision value of greater than 4 is a prerequisite for a model to be considered a good fit to the data. 


\section{References}

1. Turner NJ (2003) Directed evolution of enzymes for applied biocatalysis. Trends Biotechnol 21(11): 474-478.

2. Chaplin MF, Bucke C (1990) Enzyme technology. Press Syndicate of the University of Cambridge 1:35-38.

3. Turner NJ, Schneider M (2000) Biocatalysis and biotransformation. In: Mahmoudian M (Ed.), Elsevier Current Trends 18: 105-118.

4. Martankova L. Vladimir K (2010) Biotransformations with nitrilases. Curr Opin Chem Biol 14(2): 130-137.

5. Rispoli FJ, Shah V (2007) Mixture design as a first step for optimization of fermentation medium for cutinase production from Colletotrichum lindemuthianum. J Ind Microbiol Biotechnol 34(5): 349-355.

6. Liu L, Lin Z, Zheng T, Lin L, Zheng C, et al. (2009) Fermentation optimization and characterization of the laccase from Pleurotusostreatus strain 10969. Enzyme Microb Technol 44(6-7): 426-433.

7. Gupta N, Sahai V, Gupta R (2007) Alkaline lipase from a novel strain Burkholderiamultivorans: Statistical medium optimization and production in a bioreactor. Process Bio Chem 42(4): 518-526.

8. Correa A, Oppezzo P (2011) Tuning different expression parameters to achieve soluble recombinant proteins in E. coli: Advantages of high throughput screening. Biotechnol J 6(6): 715-730.

9. Senthilkumar SR, Ashok kumar B, Raj KC, Gunasekaran P (2005) Optimization of medium composition for alkali-stable xylanase production by Aspergillus fischeri Fxn 1 in solid-state fermentation using central composite rotary design. Bioresour Technol 96(12): 1380-1386.

10. Montgomery DC (2001) Design and analysis of experiments. John Wiley \& Sons, New York, USA, pp. 64-65.

11. Patil MD, Shinde KD, Patel G, Chisti Y, Banerjee UC, et al. (2016) Use of response surface method for maximizing the production of arginine deiminase by Pseudomonas putida. Biotechnol Rep 10: 29-37.

12. Kaushik S, Mohan U, Banerjee UC (2012) Exploring residues crucial for nitrilase function by site directed mutagenesis to gain better insight into sequence-function relationships. Int J Biochem Mol Biol 3(4): 384 391.

13. Volonte F, Marinelli F, Gastaldo L, Sacchi S, Pilone MS, et al. (2008) Optimization of glutaryl-7-aminocephalosporanic acid acylase expression in E.coli. Protein Expr Purif 61(2): 131-137.

14. Shiloach J, Fass R (2005) Growing E.coli to high cell density-a historical perspective on method development. Biotechnol Adv 23(5): 345-357.

15. Sunitha K, Lee JK, Oh TK (1999) Optimization of medium components for phytase production by E. coli using response surface methodology. Bioprocess Eng 21(6): 477-481.

16. Weickert MJ, Doherty DH, Best EA, Olins PO (1996) Optimization of heterologous protein production in Escherichia coli. Curr Opin Biotechnol 7(5): 494-499.

17. Rustler S, Miller A, Windeisen V, Chmura A, Stolz A, et al. (2007) Conversion of mandelonitrile and phenylglycinenitrile by recombinant E.coli cells synthesizing a nitrilase from Pseudomonas fluorescens EBC191. Enzyme Microb Technol 40(4): 598-606.
18. Gombert AK, Kilikian BV (1998) Recombinant gene expression in Escherichia coli cultivation using lactose as inducer. J Biotechnol 60(12): $47-54$

19. Collins T, Azevedo SJ, Branca F, Machado R, Casal M, et al. (2013) Batch production of a silk-elastin-like protein in E.coli BL21(DE3): key parameters for optimisation. Microb Cell Fact 12(1): 21.

20. Vuillemin M, Malbert Y, Laguerre S, Remaud SM, Moulis C, et al. (2014) Optimizing the production of a branching sucrase in Escherichia coli using statistical design. Appl Microbiol Biotechnol 98(11): 5173-5184.

21. Jiang Z, Arner ESJ, Mu Y, Zhang T, Yan G, et al. (2004) Expression of selenocysteine-containing glutathione S-transferase in Escherichia coli. Biochem Biophys Res Commun 321(1): 94-101.

22. Lodish H, Baltimore D, Berk A, Zipursky SL, Matsudaira P, et al. (1995) Molecular Cell Biology. Scientific American Books New York, USA.

23. Weatherburn MW (1967) Phenol-hypochlorite reaction for determination of ammonia. Anal Chem 39(8): 971-974.

24. Lambert M, Neish AC (1950) Rapid method for estimation of glycerol in fermentation solutions. Can J Res 28(3): 83-89.

25. Miller GL (1959) Use of Dinitrosalicylic acid reagent for determination of reducing sugar. Anal Chem 31(3): 426-428.

26. Hall JW, Neil B, Rollins MJ, Draper I, Thompson BG, et al. (1996) Nearinfrared spectroscopic determination of acetate, ammonium, biomass, and glycerol in an industrial Escherichia coli fermentation. Appl Spectrosc 50(1): 102-108.

27. Savari M, Esfahani SHZ, Edalati M, Biria D (2015) Optimizing conditions for production of high levels of soluble recombinant human growth hormone using Taguchi method. Protein Expr Purif 114: 128-135.

28. Papaneophytou CP, Kontopidis GA (2012) Optimization of TNFalpha overexpression in Escherichia coli using response surface methodology: purification of the protein and oligomerization studies. Protein Expr Purif 86(1): 35-44.

29. Parekh S, Vinci VA, Strobel RJ (2000) Improvement of microbial strains and fermentation processes. Appl Microbiol Biotechnol 54(3): 287301.

30. Banerjee A, Dubey S, Kaul P, Barse B, Piotrowski M, et al. (2009) Enantioselective nitrilase from Pseudomonas putida: cloning, heterologous expression, and bioreactor studies. Mol Biotechnol 41(1): 35-41.

31. Doran P (1995) Bioprocess Engineering Principles ( $\left.2^{\text {nd }} e d n\right)$, Academic press, London, UK, pp. 139-177.

32. Rigi G, Mohammadi SG, Arjomand MR, Ahmadian G, Noghabi KA, et al. (2014) Optimization of extracellular truncated staphylococcal protein A expression in Escherichia coli BL21(DE3). Biotechnol Appl Biochem 61(2): 217-225.

33. Riesenberg D, Menzel K, Schulz V, Schumann K, Veith G, et al. (1990) High cell density fermentation of recombinant Escherichia coli expressing human interferon alpha 1. Appl Microbiol Biotechnol 34(1): 77-82.

34. Rosano GL, Ceccarelli EA (2014) Recombinant protein expression in Escherichia coli: advances and challenges. Front Microbiol 5: 172. 
This work is licensed under Creative Commons Attribution 4.0 Licens DOI: 10.19080/AIBM.2017.07.555713

\section{Your next submission with Juniper Publishers} will reach you the below assets

- Quality Editorial service

- Swift Peer Review

- Reprints availability

- E-prints Service

- Manuscript Podcast for convenient understanding

- Global attainment for your research

- Manuscript accessibility in different formats ( Pdf, E-pub, Full Text, Audio)

- Unceasing customer service

Track the below URL for one-step submission https://juniperpublishers.com/online-submission.php 